\title{
Behavioural Intention of Malaysian School Teachers toward Digital Education: A Pilot Research
}

\author{
Siti Nur Aqila Anuar, Noor Fadhiha Mokhtar, Kalsitinoor Set
}

\begin{abstract}
The government recognises that the use of the Internet in education brings many benefits, but the use of computers among teachers is quite limited. The 'hardware' and 'software' management has made the teacher face many problems and did not want to use it in the classroom. As a result, computer literacy skills are a barrier among teachers and skilled teachers to operate computers and schools. This study aims to analyse the intention of Digital Education behaviour among Malaysian school teachers and to explore individual skills as an advanced component of the extended Theory of Planned Behavior. Also, this study aims to examine the role of Attitude, Subjective Normative and Perceived Behavioral as intermediaries on the relationship between individual skills and intentions to use the Internet among school teachers in Malaysia as well as to develop an extended Theory Planned Behavioral model including Individual Skills. 30 teacher was the interview to collect data as a pilot study based on a quantitative approach. In term of statistical analysis, the structural equation model (SEM) is more logical and more suitable to be used. The findings indicate that among all the hypotheses created referring to the previous study demonstrate the basis of TPB, ATT with ITU, SN with ITU and $P B C$ with ITU showing a positive impact on using the Internet towards digital education among school teachers. Additionally, after TPB's extended show of IS with ATT also has a positive relationship on the using of the Internet among teachers on the use of digital education. For researchers, this study provides a basis for future references about the digital education of the Theory of Planned Behavior.
\end{abstract}

Index Terms:- Digital education, individual skills, internet, theory planned behaviour.

\section{INTRODUCTION}

The 21st-century world is now witnessing the use of multimedia and information technology to monopolise public life generally with the motto of a borderless world. The ability of teachers to use information and communication technology is a practical approach in line with the interests of today's generation of tool-friendly and tool interfaces [1]. Digital education is one of the educational transformation efforts implemented by the Ministry of Education (MOE) under the 2013-2025 Malaysia Education Development Plan (PPPM) which focuses more on digital and Internet materials at schools. MOE named this digital education as a 21 st Century Learning (PAK-21). In [2] found that the National Education Policy was in line with Malaysia's vision to end up a created country by 2020 by PAK-21. The Internet is an

Revised Manuscript Received on July 10, 2019

Siti Nur Aqila Anuar, School of Maritime Business and Management, University Malaysia Terengganu, Malaysia.

Noor Fadhiha Mokhtar, School of Maritime Business and

Management, University Malaysia Terengganu, Malaysia.

Kalsitinoor Set, School of Maritime Business and Management,

University Malaysia Terengganu, Malaysia. important part of PAK-21's success in which digital education methods will not work perfectly without an Internet channel. According to the Education Development Master Plan (2001-2010), one of the causes is that $62 \%$ of teachers still use traditional teaching methods and even teachers do not use digital education methods to attract students towards teaching and learning Process (PDP). In [1] thinks that the government has supplied thousands of computers to schools across the country and government efforts to improve teaching professionalism. The Government intends to ensure that all teachers use computer-assisted digital materials in the PDP process as a learning tool (ABM).

Digital education is more easily understood by looking at information distribution systems in today's world computing. In education, the use of digital multimedia materials is the latest trend in learning teaching and learning sessions. However, the development of this information technology raises various reactions from various groups of people [3]. The use of the Internet and digital education system began with the launch of the Smart Elementary School Application, one of seven key applications in the Multimedia Super Corridor (MSC), in 1997, by Tun Dr Mahathir Mohamad. The development of ICT, as well as the Internet, now opens more opportunities for students and educators to explore data and knowledge and also caused social media influence to be widely used in PDP at the school level [4]. The impact of the internet and the digital system on education can be divided into three phases namely phase replacement, transition and change as stated in [5]. In the replacement phase, educators will use the digital system as a tool for teaching and learning sessions without changing the teaching method, while the transition phase involves educators using digital systems that can stimulate subsequent changes leading to new teaching methods. This change involves a fundamental switch in the role of students and educators in teaching and learning.

The government recognises that the use of the Internet in education brings many benefits, but the use of computers among teachers is quite limited. The handling of 'hardware' and 'software' software makes teachers face many problems and do not want to use them in the classroom [6]. As a result, computer literacy skills are a significant obstacle among teachers and teachers who are inadequate to operate computers and have low confidence in using computers at school and vice versa. This study will show the level of

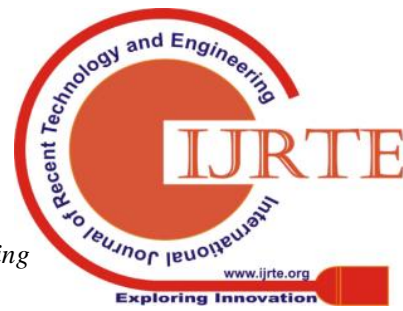




\section{BEHAVIOURAL INTENTION OF MALAYSIAN SCHOOL TEACHERS TOWARD DIGITAL EDUCATION: A PILOT RESEARCH}

computer usage in teaching and the intention of digital education behaviour among teachers. It is therefore important to analyse the behaviour of school teachers in Malaysia and to identify the element that influence them. The existing theory of Planned Behaviour (TPB) Theory with has combined to the Individual Skills. Therefore, this study can help the MOE to devise strategies to support and motivate academics to use the Internet digitally by making more changes in school teaching and learning processes to become e-schools.

\section{LITERATURE REVIEW}

This paper has investigated the intention of Malaysian school teachers toward digital education. The hypothesis of the past research relationship among variable is determine whether all of independent variable directly or indirectly influence on behavioural intention which is the Internet usage.

\section{A. Extended Theory of Planned Behavior (TPB)}

The theory of planned behavior (TPB) model developed by [7] is used as one of the most recognized testing instruments for measuring the cognitive ingredient of the consumers. TPB proposes that behavior is determined by the combination of an individual's intentions to engage in a particular behavior. According to [7], even if a mortal's attitude and subjective norm are in favour of performing a particular behavior, a belief that the behavior is too difficult to perform may cause the person to intend not to perform it. In summary, then, in [7] asserted that intention are determined by attitudes, subjective norms, and perceived behavioral control [8]. Therefore, it was modified by adding one core constructs which is individual skill. The details of these construct are as follows.

\section{B. Individual Skills (IS)}

According to [9], individual skills (IS) are the ability to do something by using knowledge and it is different from one another. The process of teaching and learning is a process that involves the interaction of teachers with students and the effectiveness of teachers' education is dependent to how teachers can adapt and understand the problem of student learning.

There are various aspects that influence the quality of teacher teaching. Among them are the knowledge and knowledge the teacher possesses, the methods used by teachers in implementing the teaching process and teacher personality. These aspects must be identified and understood. Among these issues is the teaching experience of a teacher, the subject taught by the teacher and the training that the teacher has attended [10].

In [11] claimed that skills has a positive relationship with the intention, while in [12] stated that finding more positive attitudes toward the behavior and higher intentions to produce such behavior. However, in [13] found that individual skills significant factors with subjective norms and individual's skills are positive related with behavior to usage the computer [14]. Based on the arguments above, it is hypothesize that:

H1: There is a positive significant effect on Individual Skills with the relationship of intention to use among school teachers.

$\mathrm{H} 2$ : Individual skills are positively significant related to an attitude among schools teachers

H3: Individual skills are positively significant related to subjective norms among schools teachers.

H4: Individual skills are positively related to perceive behavioral among school teachers.

\section{Attitude (ATT)}

The study of attitudes has been exchanged to social psychological theory development since the birth of the field, and psychological insights into attitudes have enjoyed tremendous imp enactment in a wide range of applied settings, including politics, health, merchandising education, and much more [15]. According to [16], attitudes are hypothetical constructs that refer to "psychological learning that is expressed by a particular entity with some arc degree of party favour or disfavour". Attitudes are realised as internal cognitive processes that control one's behaviour. Thus, an attitude expresses itself as a tendency to always act in the same mode, according to the situations in which individuals are placed [16].

A study by [17] found that attitude will influence their behavioral intention and attitude was reported to be the most important factor that predicted the intention [18]. Hence, the next hypothesis is follows:

H5: Attitude is positively significant related to intention to use the Internet among school teachers.

\section{Subjective Norms (SN)}

In [19] found that subjective norm can be defined as someone's perception of the pressing of his/her relatively talented mass to need to compare whether certain particular behaviour perform or not. The researchers also conclude that the military posture of the relationship between subjective norm and intention to share knowledge is extremely influenced by facilitating positive organizational climate [20]. Subjective norms consist of a person's belief about whether significant others think he or she should engage in the behavior and are assumed to assess the social insistence on the individual to perform or not to perform a particular behavior [21]. Previous studies found that subjective norms have significantly towards intention [22] and the hypothesized is follows:

H6: Subjective Norms is positively significant related to intention to use the Internet among school teachers.

\section{E. Perceived Behavioral Control (PBC)}

In [23] defines behavioural control as follows: "this factor refresh to the perceived rest or difficultness playacting the behaviour and it assume to reflect experience as well as anticipates obstruction and obstacle", which means that these factors reflect the perceptions would be challenging or not perform an action and assumed a reflection of experience and expectation of obstacles. 
Perceived behavioural control can be measured by asking direct doubt about the capability to perform a behaviour or indirectly by notion about the ability to mess with particular inhibiting or facilitating factors and is assumed sometimes to have a direct upshot on behaviour [24]. Further, perceived behaviour is a control behaviour of the individual's perception about the simplicity or difficulty in performing specific behaviours [25] and can determine a person's perception toward the ease or difficulty of being a whistleblower [26].

In general, attitude toward the behavior and perceived behavioral control significantly explained variation in intention [27] and perceived behavioral control significantly relationships between beliefs and intention [28]. Hence, our final hypothesis is as follows:

H7: Perceived Behavioral is positively significant related to intention to use the Internet among school teachers.

\section{F. Intention to Use (ITU)}

Most behaviour reaction based on intentions reflect of conscious plan or decision. [29]. The TPB was developed to predict an individual's behavioural intentions toward a specific effect [7]. Behavioural Intention of Use is a behavioural tendency to use a technology [30]. Then, TPB postulate that the individual's behavioural intention is influenced directly by motivating factors in their decisiondevising mental process [31].

The Internet is also used for purposes other than academic activities; then the Internet provides an additional opportunity while understanding the practice of usage and what drives them to use the Internet is required information for web-designers and to encourage the more excellent use of the Internet in the future [32]. The abundance of information provided is an attraction of the Internet to its users. Further, the educators and learners often use the internet to solve problems either in learning tasks or in everyday issues and the internet one of the new learning media that is through the internet. High usage the rapid development of internet access devices and increasingly lower prices will also encourage the discovery of discoveries both theoretically and to be the basis for education [33].

The more favourable attitudes and subjective norms that combined with greater perceived behavioural control, make the stronger of the intention for environmentally-oriented behaviour [34]. In this study, to conceptualise the TPB as part of a broader conceptual framework that examined the tangible - or 'real' - outcomes that the intention to use the Internet among the school teacher toward digital education.

\section{G. Development of Theoretical Framework}

Previous studies have agreed to measure look of mastery associated with individual skills along with available resources and management sustenance in Fig. 1 [35]. In [36] proposed the theory of planned behaviours (TPB) to suggest that environmental pressure caused by norms would influence original behavioural intention.

\section{METHODOLOGY}

The unit of analysis of this study is at high school government only. The respondent of this study were the teachers that have intention to use digital education in classroom learning and teaching for teachers' day-to-day use and convenience.

\section{A. Data Collection and Sampling}

To collect data from teachers, we first need permission from MOE, Pahang state education, District Education Officer (PPD) and school administrators. Afterwards, 30 sets of questionnaires were distributed among teachers in selected schools. Participation is voluntary, and teachers are required to fill out a questionnaire. This survey was conducted at two secondary schools in the district of Bera, Pahang and this study was conducted for one month.

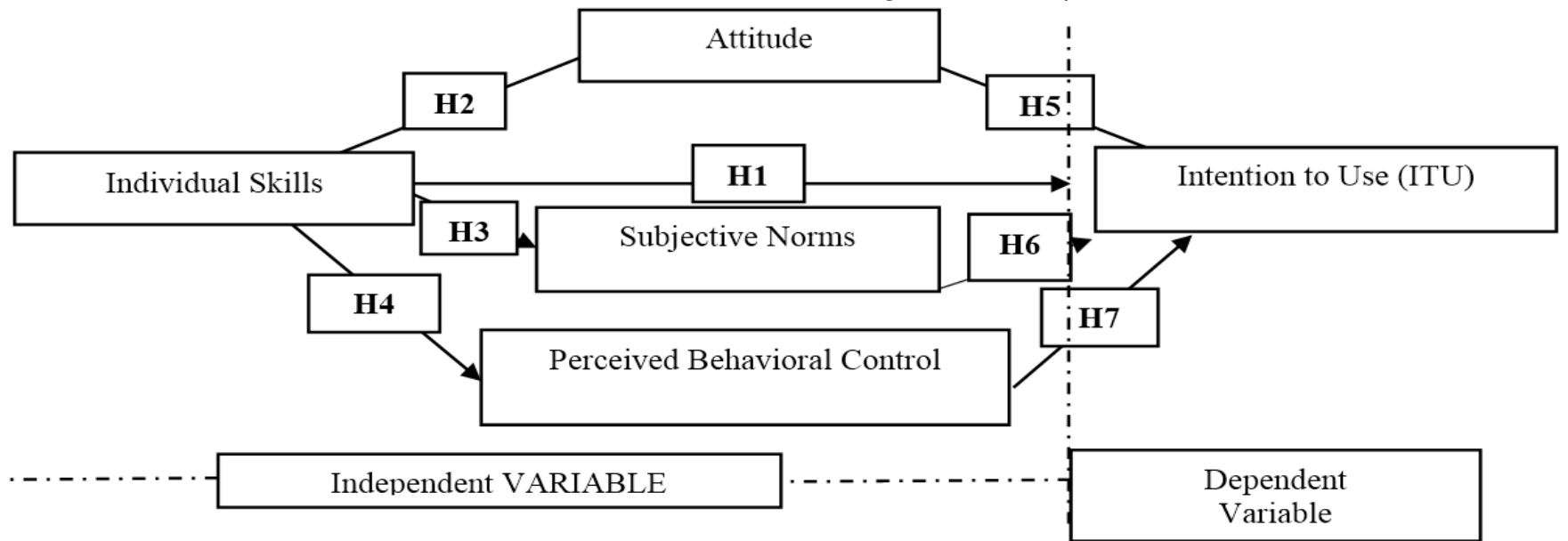

Fig. 1: Research model

\section{B. Instrument Development}

Rationalist believes in employing quantitative approach for data analysis and musical accompaniment objectivity to define their ontological statements [37]. Therefore, questionnaires have been developed to measure teachers' Intention to Behaviour in digital education. The questionnaire was divided into two parts. The first part of the questionnaire was about respondents' demographic profiles and general interrogative related to digital education among teachers. While, the second part of the questionnaire covers the items measured namely Individual Skills, Attitudes, Subjective Norms, Perceived Behavioural Control and Intention to use. Measurement

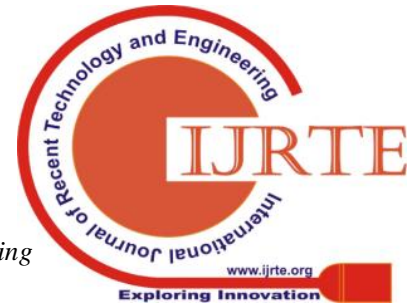




\section{BEHAVIOURAL INTENTION OF MALAYSIAN SCHOOL TEACHERS TOWARD DIGITAL EDUCATION: A PILOT RESEARCH}

item of Intention behaviour was adopted from [38]. Each piece is subtracted on the Likert scale of five points from 1 (strongly disagree) to 5 (strongly agree). The questionnaire was created and operated in two voice communications namely Bahasa Malaysia and English.

\section{Respondent Profile}

The sample is 30 , where $16.7 \%$ are male and the rest are female. Most respondents $36.7 \%$ are between 35 and 44 years old. $26.7 \%$ were above 25 to 34 years old and above 55 years old. Two respondents, 6.7\%, did not answer this question. All the samples in the study were Malay (100\%), $66.7 \%$ were teachers, and the Couse leaders is $23.3 \%$ while the coordinator is $6.7 \%$ and $3.3 \%$ were school principals. $60 \%$ of respondents have ten years of teaching experience. $53.3 \%$ are teachers from urban areas while $46.7 \%$ are teachers from rural areas. Furthermore, $70 \%$ of respondents had at least a Bachelor's Degree. Many teachers in this survey had education grade (DG) 48 of $30 \%$ followed by DG52 of $26.7 \%$. About $60 \%$ of teachers have a monthly salary estimate of RM6001 to RM8000 per month followed by $26.7 \%$ for an estimated salary of RM4001 to RM6000. For job status, $90 \%$ are permanent teachers. About $40 \%$ of teachers allocate 2 to 3 hours a day to access digital education. There were 3 respondents who did not answer this question $(10 \%)$.

\section{RESULTS AND ANALYSIS}

The information was analysed using Smart PLS version 3.2.7 software developed by [39] which is a variance based on structural equation modelling (SEM). SEM is a technique to estimate the causal relationship among variables. Following the two-stage analytical procedure, the measurement model is analysed first to assess the reliability and validity of the instrument and then hypotheses were tested through the structural model.

The item verbal description of both measure model and structural model are summarised in the following discussion section. It is a suitable choice to present the analysis instead of using covariance-based SEM because this study intended to predict the relationship between the variables in the research model rather than reproducing the covariance matrix to achieve model fit [40]. SEM is a technique to estimate the causal relationship among variables. Following the two-stage analytical procedure, the measurement model is analysed first to assess the reliability and validity of the instrument and then hypotheses were tested through the structural model. The detail descriptions of both measurement model and structural model are summarised in the following sections.

\section{A. Measurement Model}

The first test is convergent validity which reflects whether a particular item measures a latent variable that it is supposed to be measured [41]. In [40] proposed that the loading and average variance explain (AVE) must exceed 0.5 , and the composite reliability $(\mathrm{CR})$ must reach 0.7 to ensure that convergent validity is established in the model. Thus, it can be confirmed that the measurement model showed the evidence of convergent validity.

Table 1: Result of measurement model

\begin{tabular}{|c|c|c|c|c|}
\hline Construct & Items & Loadings & AVE & CR \\
\hline \multirow{6}{*}{$\begin{array}{c}\text { Attitude } \\
\text { (ATT) }\end{array}$} & ATT1 & 0.861 & 0.674 & 0.925 \\
\hline & ATT2 & 0.867 & & \\
\hline & ATT3 & 0.745 & & \\
\hline & ATT4 & 0.800 & & \\
\hline & ATT5 & 0.760 & & \\
\hline & ATT6 & 0.883 & & \\
\hline \multirow{5}{*}{$\begin{array}{l}\text { Individual } \\
\text { Skills (IS) } \\
\end{array}$} & IS1 & 0.886 & 0.669 & 0.910 \\
\hline & IS2 & 0.801 & & \\
\hline & IS3 & 0.824 & & \\
\hline & IS4 & 0.824 & & \\
\hline & IS5 & 0.747 & & \\
\hline \multirow{4}{*}{$\begin{array}{c}\text { Intention to } \\
\text { use (ITU) }\end{array}$} & ITU1 & 0.828 & 0.724 & 0.913 \\
\hline & ITU2 & 0.880 & & \\
\hline & ITU3 & 0.833 & & \\
\hline & ITU4 & 0.862 & & \\
\hline \multirow{8}{*}{$\begin{array}{c}\text { Perceived } \\
\text { Behavioral } \\
\text { (PBC) }\end{array}$} & PBC1 & 0.791 & 0.634 & 0.924 \\
\hline & & & & \\
\hline & PBC2 & 0.831 & & \\
\hline & PBC3 & 0.843 & & \\
\hline & PBC4 & 0.801 & & \\
\hline & PBC5 & 0.753 & & \\
\hline & PBC6 & 0.756 & & \\
\hline & PBC6 & 0.794 & & \\
\hline \multirow{8}{*}{$\begin{array}{c}\text { Subjective } \\
\text { Norms (SN) }\end{array}$} & SN1 & 0.757 & 0.642 & 0.935 \\
\hline & SN2 & 0.796 & & \\
\hline & SN3 & 0.832 & & \\
\hline & SN4 & 0.831 & & \\
\hline & SN5 & 0.823 & & \\
\hline & SN6 & 0.781 & & \\
\hline & SN7 & 0.764 & & \\
\hline & SN8 & 0.825 & & \\
\hline
\end{tabular}




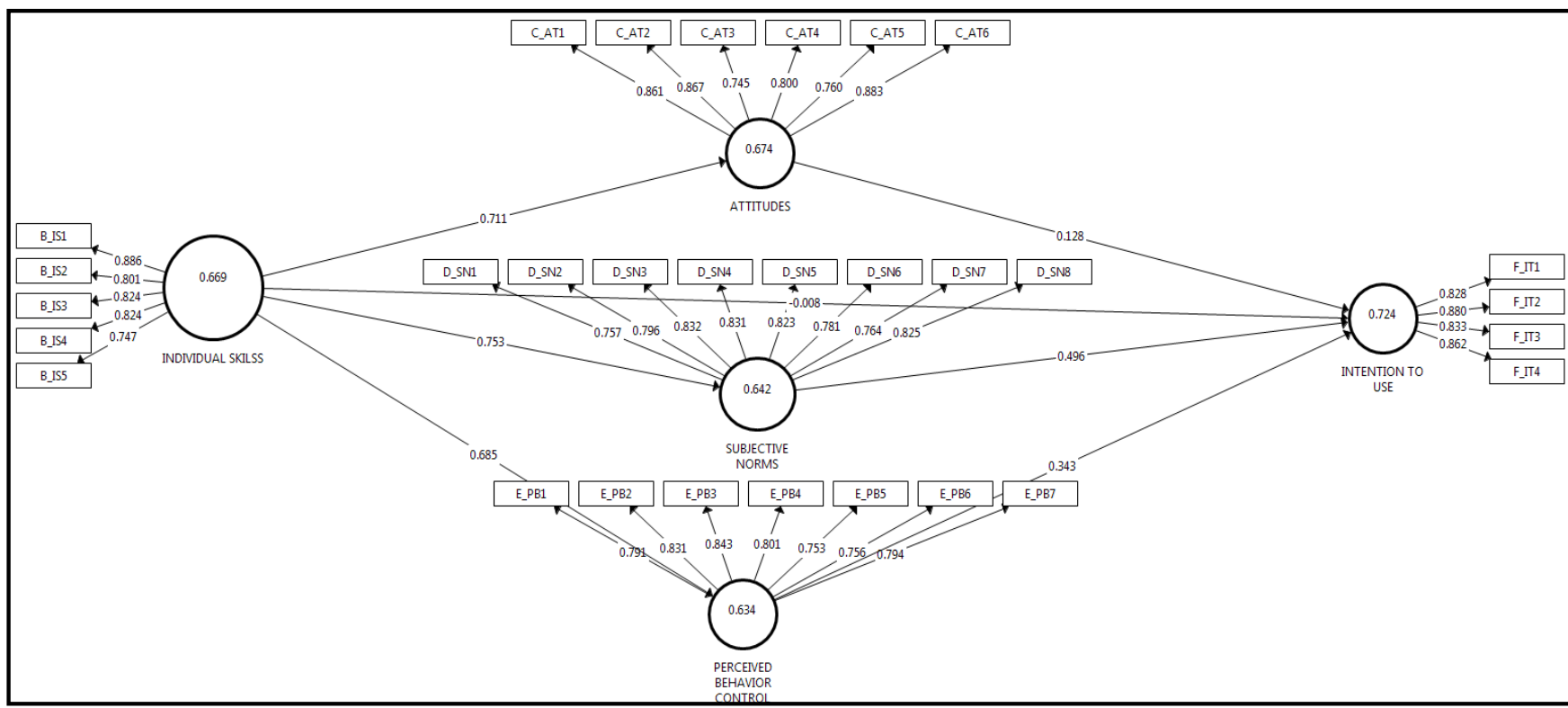

Fig. 2: Measurement model

Convergent validity is ascertained by examining indicator loadings. In this work, factor loading values are supported as recommended by [42], the doorsill level of 0.6. All indicators values were above 0.6 that indicates the validity of the construct. Table 1 and Fig. 2 describe the resolution of the measured model. Discriminant validity assesses the extent to which a construct and its indicators differ from another idea and its index. Discriminant validity is measured by examining the correlation between the measures of the potential drop imbrication construct [43].

According to [44], the average variance shared between each construct and its measure should be greater than the variation shared between the constructs and other constructs. Table 2 showed the results of discriminant validity; all the bias values (square origin of AVE) are higher than off-diagonal values (correlations between the construct) indicates that the measure is discriminant.

Table 2: Discriminant validity of measurement model

\begin{tabular}{|c|c|c|c|c|c|}
\hline & ATT & IS & ITU & PBC & SN \\
\hline ATT & 0.821 & & & & \\
\hline IS & 0.711 & 0.818 & & & \\
\hline ITU & 0.722 & 0.692 & 0.851 & & \\
\hline PBC & 0.759 & 0.685 & 0.824 & 0.796 & \\
\hline SN & 0.683 & 0.753 & 0.847 & 0.784 & 0.801 \\
\hline
\end{tabular}

Note: Bold values indicates the square root of AVE of each construct

Table 3 demonstrates that all the loadings are greater than the correspondent cross-loadings. According to [45], discriminant validity can be assessed through the multitrait and multimethod intercellular substance namely the Heterotrait-Monotrait Ratio (HTMT). Using the HTMT criterion, if the values are greater than HTMT 0.85 indicates there was a problem with discriminant validity. As a display in Table 4, all the costs are lower than the required threshold value indicating that discriminant validity is valid for this study. Besides, the results of HTMT inference also show that confidence time interval does not show a value of 1 on any of the construct, which also confirms discriminant validity.

Table 3: Heterotrait-Monotrait Ratio (HTMT)

\begin{tabular}{|c|c|c|c|c|c|}
\hline & ATT & IS & ITU & PCB & SN \\
\hline ATT & & & & & \\
\hline IS & 0.796 & & & & \\
\hline ITU & 0.804 & 0.775 & & & \\
\hline PBC & 0.834 & 0.760 & 0.824 & & \\
\hline SN & 0.743 & 0.826 & 0.833 & 0.847 & \\
\hline
\end{tabular}

\section{B. Hypothesis Testing}

Next, to test the hypotheses we used the path analysis. Hypotheses were tested running a bootstrapping procedure with a resample of 30 , as suggested by [46]. The result reveals in table 4 show that five hypotheses were supported $(\mathrm{H} 2, \mathrm{H} 4, \mathrm{H} 5, \mathrm{H} 6$ and $\mathrm{H} 7)$ and another two hypotheses were found as not supported (H1 and H3).

Individual Skills $(\beta=0.046, \mathrm{t}=0.923: \mathrm{LL}=-0.064$, $\mathrm{UL}=0.270, \mathrm{p}<0.175),(\beta=8.545, \mathrm{t}=8.704: \mathrm{LL}=$ $0.577, \mathrm{UL}=0.793, \mathrm{p}<0.000),(\beta=8.093, \mathrm{t}=0.048: \mathrm{LL}$ $=-0.174, \mathrm{UL}=0.195, \mathrm{p}<0.481)$ and $(\beta=6.802, \mathrm{t}=$ $6.987: \mathrm{LL}=0.515, \mathrm{UL}=0.783, \mathrm{p}<0.000)$ and Attitude $(\beta=0.937, \mathrm{t}=8.568: \mathrm{LL}=0.598, \mathrm{UL}=0.839, \mathrm{p}<0.000$ ) .

Meanwhile, Subjective Norms $(\beta=2.979, \mathrm{t}=2.076$ : $\mathrm{LL}=0.118, \mathrm{UL}=0.485, \mathrm{p}<0.010)$ and Perceived Behavior Control $(\beta=2.328, \mathrm{t}=3.189$ : $\mathrm{LL}=0.306, \mathrm{UL}=$ 0.704, $\mathrm{p}<$ 0.002). Table 6 demonstrates the PLS estimation results. 
BEHAVIOURAL INTENTION OF MALAYSIAN SCHOOL TEACHERS TOWARD DIGITAL EDUCATION: A PILOT RESEARCH

Table 4: Hypotheses testing

\begin{tabular}{|c|c|c|c|c|c|c|c|}
\hline Hypotheses & Constructs & $\beta$ & T-Value & P-Value & LL & UL & Result \\
\hline H1 & IS $\rightarrow$ ITU & 0.046 & 0.923 & 0.175 & -0.064 & 0.270 & Unsupported \\
\hline H2 & IS $\rightarrow$ ATT & 8.545 & 8.704 & 0.000 & 0.577 & 0.793 & Supported \\
\hline H3 & IS $\rightarrow$ SN & 8.093 & 0.048 & 0.481 & -0.174 & 0.195 & Unsupported \\
\hline H4 & IS $\rightarrow$ PBC & 6.802 & 6.987 & 0.000 & 0.515 & 0.783 & Supported \\
\hline H5 & ATT $\rightarrow$ ITU & 0.937 & 8.568 & 0.000 & 0.598 & 0.839 & Supported \\
\hline H6 & SN $\rightarrow$ ITU & 2.979 & 2.076 & 0.010 & 0.118 & 0.485 & Supported \\
\hline H7 & PBC $\rightarrow$ ITU & 2.328 & 3.189 & 0.002 & 0.306 & 0.704 & Supported \\
\hline
\end{tabular}

\section{DISCUSSION}

The objective of this study is to analyse the intention of conducting Digital Education among school teachers in Malaysia. By adopting the TPB Framework, this study has revealed essential determinants that can influence the intention. This study has confirmed that the hypotheses for Individual skills on the attitudes and behaviours of the perceived behaviour, the attitude of the attitude used the norm of norms to be used, and the control of the perceived behaviour for the intention to use.

An individual skill was found to have a positive relationship with the attitude among school teachers. The finding was supported by [12]. Individual skills are something that is closely related to the attitude and $\mathrm{H} 2$ is supported. The individual skills were found a positive relationship with perceived behavioural control supported by [14] and the H4 is supported. Individual skills will influence the perceived behaviour control associated with them because the ability of their self will help to improve perceived behavioural control of a person. The recent study by [17] found that the attitudes will influence the behavioural intention and have supported from [18] that have reported the attitude to be the most important factor that predicted the intention. A positive attitude will directly affect the intention of the behaviour. Then attitude is essential to measure the practice of intention. Thus, the H5 is supported in this study.

Scholar has reported that subjective norms have significantly toward intention by [22]. The subjective norm factors and the influence of the surroundings will influence intention and H6 is supported. In general, attitude toward the behaviour and perceived behavioural control significantly explained variation in intention reported and have support from [28] that prove the significant relationships between beliefs and intention and $\mathrm{H} 7$ is supported.

However, the hypotheses with Individual skills to purpose to use and subjective norms were found as unsupported. In general, the study revealed that the TPB framework is still useful in explaining the intention to use digital education among school teachers in Malaysia. For this researcher provides the basis for further improvement of the adoption model of TPB while for practitioners improving individual skills can increase user usage. For suggesting that the future study should include more respondent to get more significant data and extend the survey to all teaching staff in Malaysia including teachers in Primary Schools.
Regarding the theory of constructing this study try to develop a new method by putting a new variable in TPB integration and perceived individual skills. It is important to note that individual skills are changing new compatible with TPB models. Therefore, the proposed model makes a significant contribution to the emerging digital literary literature, especially about the use of teaching and learning in schools. In the context of management, the results of this study highlight some of the critical factors that lead to the adoption of teachers in schools. First, although other TPB factors such as Attitudes, Subjective Norms and Perceived Behavioural Control have a significant impact on consumer intentions, therefore substantial performance analysis has shown that among other factors, individual skills maintain the maximum effect of teachers' desire to adopt education digitally. Secondly, the most important contribution in this study is the study of consumer feedback. We have found that the intentions of teachers can bring the teachers' suggestions. Finally, the outcome has also revealed that individual skills are considered to be among the key factors in determining the user's intentions. Therefore, we suggest that teachers' intentions on the use of digital education can be enhanced if policymakers focus on factors such as individual skills to enhance teachers' confidence to teach using digital education.

\section{B. Limitations and Directions for Future Research}

The field of the study has the limitation that gives the impulse for further research in the area of the probe. First, our analysis is cross-sectional and measures the teachers' intention in using digital education which may be less common than longitudinal report, and this study predicts the user's intention. Hence, future research can be done on the behaviour of real consumer customers and further increase the number of respondents to obtain more significant data. Also, this study should involve teachers in government and private schools comprising primary and secondary school teachers to learn more about the provision of teachers in Malaysia on digital education now.

\section{CONCLUSION}

This study has contributed to research by explaining the ongoing features of knowledge sharing and the determinants of continuous intentions in the context of digital education and intention to use. Theoretical 
contributions are presented below: First, this article contributes to providing a better understanding of ongoing knowledge sharing and identifying the theoretical foundations that describe this current behavior. Secondly, this study uses the theory of Planned Behavior, to explain more about what determines Intention to use in the community of teachers towards digital education. This study follows strictly as the presumption of this theoretical model by using only the constant associated factors as a determinant.

In the context of management, this study provides information on the Intention of teachers in using digital education to MOE. Based on the empirical results of this study, individual skills acquired for a teacher do not affect the intention to use digital education among school teachers. This demonstrates the ability of teachers on electronic items and digital literacy that needs to be applied in schools is still in good stead. This is because teachers still need sufficient training to use and apply this digital education better.

This data can help MOE realise the new standardisation of Digital Education among teachers. The findings of this study will help the Malaysian Education Ministry to devise strategies to support and motivate academicians to use the Internet more in their work to prepare for changes in school teaching and learning processes to become e-schools. The government needs to generate a new policy to address one of the weaknesses to achieving e-school goals is the excessive use of the Internet among teachers in school during school hours. Also, governments need to enforce laws over the use of the Internet and not on school-related matters. Action should also be taken on teachers who violate this law, and the MOE should develop new guidelines for planning to increase digital use in the PDP process. Also, the MOE can also organise courses at lower levels to higher education levels to enhance teachers' knowledge in digital. Likewise, the State Education Department (JPN) and the District Education Office (PPD) can also handle and maintain basic digital courses in the field of education as a whole.

In conducting this field of study, some restrictions have been recognised and created proposals for future research. This study has provided various brainstorm into a manageable success factor. However, quantitative methods employed using structured questionnaires limit the potential to determine the success factors that MOE can control. Therefore, qualitative approaches are recommended for future research, to conduct in-depth interviews with Malaysian educators in the use and acceptance they are digitally educated and what problems they face for the MOEs are looking for solutions for the importance of the education sector in Malaysia.

Also, this study may be enlarged as this study is limited to educators at school only by the government and more closely linked to teachers in schools only. Therefore, it is proposed that time be extended to widen the teachers at private schools or to educators at higher institutions in Malaysia.

\section{ACKNOWLEDGMENT}

The author would like to thank MOE for granting permission for this study involving teachers in selected government schools in Malaysia and thank you to School of Maritime Business and Management, University Malaysia Terengganu (UMT) to give permission to use research and support facilities in this study.

\section{REFERENCES}

1. M. A. Lubis, W. N. S. W. Hassan, and M. I. Hamzah, "Tahap pengetahuan dan kesediaan guru-guru pendidikan Islam sekolah menengah di selangor terhadap penggunaan multimedia dalam pengajaran pendidikan Islam," ASEAN Comparative Education Research Journal on Islam and Civilization, 1(1), 2017, pp. 1-3.

2. M. Abdullah, and K. Osman, "21st century inventive thinking skills among primary students in Malaysia and Brunei," Procedia-Social and Behavioral Sciences, 9, 2010, pp. 1646-1651.

3. M. M. Awang, A. R. Ahmad, and N. S. A. Talib, "Penggunaan multimedia dalam pendidikan sejarah pada abad ke-21 dan hubungannya dengan minat belajar sejarah," Jurnal Pemikir Pendidikan, 7, 2016, pp. 57-72.

4. M. N. M. Yusuf, and Z. Tahir, "Kepentingan penggunaan media sosial teknologi maklumat dalam pendidikan IPTA," Journal of Social Sciences and Humanities, 12(3), 2017, pp. 1-10.

5. I. N. Umar, and N. Jamiat, "Pola penyelidikan ICT dalam pendidikan guru di Malaysia: Analisis prosiding teknologi pendidikan Malaysia," Journal of Educators and Education/Jurnal Pendidik dan Pendidikan, 26(1), 2011, pp. 1-14.

6. K. Shanmugam, and B. Balakrishnan, "Kerangka Panduan Efektif Pengajaran Dan Pemudahcaraan (PdPc) sains menggunakan Information Communication Technology (ICT) di Sekolah Jenis Kebangsaan Tamil (SJK) (TAML)," Sains Humanika, 10(1), 2017, pp. 25-35.

7. I. Ajzen, "The theory of planned behavior," Organizational Behavior and Human Decision Processes, 50(2), 1991, pp. 179-211.

8. D. Trafimow, "Habit as both a direct cause of intention to use a condom and as a moderator of the attitude-intention and subjective norm-intention relations," Psychology and Health, 15(3), 2000, pp. 383-393.

9. M. C. Ching, and J. Badusah, "Sikap guru Bahasa Melayu terhadap penggunaan Teknologi Maklumat dan Komunikasi (ICT) dalam pengajaran di sekolahsekolah rendah di Bintulu, Sarawak," Malaysian Journal of Education, 35(1), 2010, pp. 59-65.

10.A. Yahaya, Tahap penguasaan kemahiran manipulatif di kalangan guru pelatih kimia Universiti Teknologi Malaysia. Bachelor thesis, Johor: Universiti Teknologi Malaysia, 2007. 
11.J. Holwerda, The relationship between entrepreneurial skills and intentions. Bachelor thesis, Kainuu: Kajaani University of Applied Sciences, 2018.

12. N. J. B. Mahomed, "Hubungan antara pengharapan, sikap terhadap perkhidmatan kaunseling dan niat untuk mendapatkan perkhidmatan kaunseling dalam kalangan pelajar berisiko. Master thesis, Selangor: Universiti Putra Malaysia, 2014.

13.F. H. Fanning, and J. M. Ricks, "Attitudes, social norms and perceived behavioral control factors influencing participation in a cooking skills program in rural Central Appalachia," Global Health Promotion, 24(4), 2017, pp. 43-52.

14.M. Igbaria, S. Parasuraman, and J. Baroudi, "A motivational model of microcomputer usage," Journal of Management Information Systems, 13(1), 1996, pp. 127-143.

15.L. C. Howe, and J. A. Krosnick, "Attitude strength," Annual Review of Psychology, 68, 2017, pp. 327-351.

16.W. P. McCarty, J. S. Zhao, and B. E. Garland, "Occupational stress and burnout between male and female police officers: Are there any gender differences?" Policing: An International Journal of Police Strategies and Management, 30(4), 2007, pp. 672-691.

17.S. M. Kabir, A. Haque, and A. Sarwar, "Factors affecting the intention to become an entrepreneur: A study from Bangladeshi business graduates perspective," International Journal of Engineering and Information Systems, 1(6), 2016, pp. 10-19.

18.S. Brouwer, B. Krol, M. F. Reneman, U. Bültmann, R. L. Franche, J. J. L. Van Der Klink, and J. W. Groothoff, "Behavioral determinants as predictors of return to work after long-term sickness absence: An application of the theory of planned behavior," Journal of Occupational Rehabilitation, 19(2), 2009, pp. 166174.

19.R. Teehan, and W. Tucker, "A simplified lean method to capture customer voice," International Journal of Quality and Service Sciences, 2(2), 2010, pp. 175-188.

20. M. S. Rahman, A. M. Osmangani, N. M. Daud, and F. A. M. AbdelFattah, "Knowledge sharing behaviors among non academic staff of higher learning institutions: Attitude, subjective norms and behavioral intention embedded model," Library Review, 65(1/2), 2016, pp. 65-83.

21.R. E. Rhodes, K. S. Courneya, and L. W. Jones, "The theory of planned behavior and lower-order personality traits: Interaction effects in the exercise domain," Personality and Individual Differences, 38(2), 2005, pp. 251-265.

22.S. Chuchinprakarn, Application of the theory of reasoned action to on-line shopping. 2005, Available: https://www.bu.ac.th/knowledgecenter/epaper/jan_jun e2005/supanat.pdf.

23. I. Ajzen, Attitudes, Personality and Behavior. Illinois: Dorsey Press, 1988.

24.J. Cestac, F. Paran, and P. Delhomme, "Young drivers' sensation seeking, subjective norms, and perceived behavioral control and their roles in predicting speeding intention: How risk-taking motivations evolve with gender and driving experience," Safety Science, 49(3), 2011, pp. 424-432.

25.C. W. Utami, "Attitude, subjective norms, perceived behavior, entrepreneurship education and self-efficacy toward entrepreneurial intention university student in Indonesia," European Research Studies Journal, 20(2A), 2017, pp. 475-495.

26.F. R. Anggraini, and F. A. Siswanto, "The role of perceived behavioral control and subjective norms to internal auditors' intention in conveying unethical behavior: A case study in Indonesia," Review of Integrative Business and Economics Research, 5(2), 2016, pp. 141-150.

27. A. Y. Smith, Attitude, subjective norm, and perceived behavioral control as indicators for nurse educators' intention to use critical thinking teaching strategies: A structural equation model analysis. $\mathrm{PhD}$ thesis, Michigan: Andrews University, 2015.

28. M. A. Close, L. A. Lytle, D. G. Chen, and J. V. Anthony, "Using the theory of planned behavior to explain intention to eat a healthful diet among Southeastern United States office workers," Nutrition and Food Science, 48(2), 2018, pp. 365-374.

29.R. E. Rhodes, and L. Dickau, "Moderators of the intention-behaviour relationship in the physical activity domain: A systematic review," British Journal of Sports Medicine, 47(4), 2013, pp. 215-225.

30.F. D. Davis, "Perceived usefulness, perceived ease of use, and user acceptance of information technology," MIS Quarterly, 13(3), 1989, pp. 319340 .

31.K. K. F. So, H. Oh, and S. Min, "Motivations and constraints of Airbnb consumers: Findings from a mixed-methods approach," Tourism Management, 67, 2018, pp. 224-236.

32.T. Ramayah, M. Jantan, and B. Aafaqi, "Internet usage among students of institutions of higher learning: The role of motivational variables," 1st International Conference on Asian Academy of Applied Business Conference, 2003, pp. 134-144.

33.M. Aristian, D. B. Setyohadi, and B. L. Sinaga, "Faktor yang mempengaruhi niat penggunaan elearning oleh mahasiswa pada Universitas Atmajaya Yogyakarta," Seminar Nasional Teknologi Informasi dan Komunikasi, 2017, pp. 322-327.

34. M. Ham, M. Jeger, and A. F. Ivković, "The role of subjective norms in forming the intention to purchase green food," Economic Research-Ekonomska Istraživanja, 28(1), 2015, pp. 738-748.

35.A. Buhmann, and P. S. Brønn, “Applying Ajzen's theory of planned behavior to predict practitioners' intentions to measure and evaluate communication outcomes," Corporate Communications, 23(3), 2018, pp. 377-391. 
36.I. F. Ajzen, and M. M. Fishbein, Understanding Attitudes and Predicting Social Behavior. New Jersey: Prentice-Hall, 1980.

37.M. A. Ghani, S. Rahi, N. M. Yasin, and F. M. Alnaser, "Adoption of internet banking: Extending the role of Technology Acceptance Model (TAM) with ecustomer service and customer satisfaction," World Applied Sciences Journal, 35(9), 2017, pp. 1918-1929.

38.C. J. Armitage, and M. Conner, "Efficacy of the theory of planned behaviour: A meta-analytic review," British Journal of Social Psychology, 40(4), 2001, pp. 471-499.

39.C. Ringle, D. D. Silva, and D. Bido, "Structural Equation Modeling with the SmartPLS," Brazilian Journal of Marketing, 13(2), 2015, pp. 56-73.

40.J. F. Hair Jr, G. T. M. Hult, C. Ringle, and M. Sarstedt, A Primer on Partial Least Squares Structural Equation Modeling (PLS-SEM). Cliafornia: Sage Publications, 2016.

41.N. Urbach, and A. Frederik, "Structural equation modeling in information systems research using partial least squares," Journal of Information Technology Theory and Application, 11(2), 2010, pp. $5-40$.

42.W. Chin, "The partial least squares approach to structural equation modeling," in Modern Methods for Business Research, G. A. Marcoulides, Ed. New York: Psychology Press, 1998, pp. 295-358.

43.C. Fornell, and D. F. Larcker, "Structural equation models with unobservable variables and measurement error: Algebra and statistics," 18(3), 1981, pp. 382388.

44.D. R. Compeau, and C. A. Higgins, ""Computer selfefficacy: Development of a measure and initial test," MIS Quarterly, 19(2), 1995, pp. 189-211.

45.J. Henseler, C. M. Ringle, and M. Sarstedt, "A new criterion for assessing discriminant validity in variance-based structural equation modeling," Journal of the Academy of Marketing Science, 43(1), 2015, pp. 115-135.

46.J. F. Hair Jr, M. Sarstedt, L. Hopkins, and V. G. Kuppelwieser, "Partial least squares structural equation modeling (PLS-SEM): An emerging tool in business research," European Business Review, 26(2), 2014, pp. 106-121. 